
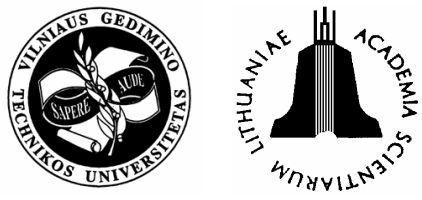

ISSN 1392-3730 print / ISSN 1822-3605 online

JOURNAL OF CIVIL ENGINEERING AND MANAGEMENT

http:/www.jcem.vgtu.lt

2006, Vol XII, No 3, 247-253

\title{
EFFECT OF RISK ON ECONOMIC EFFICIENCY OF OVERCLADDING SYSTEM
}

\author{
Ewa Marcinkowska, Mariusz Rejment \\ Wroctaw University of Technology, Institute of Building Engineering, Pl. Grunwaldzki 11, \\ 50-370 Wroctaw, Poland. E-mail: ewa.marcinkowska@pwr.wroc.pl; mariusz.rejment@pwr.wroc.pl
}

Received 22 Aug 2005; accepted 22 Dec 2005

\begin{abstract}
When a decision is taken about assembling an overcladding system on building external walls, an expected profit is calculated according to the economic discounting formulae. However, these formulae do not take into account the unplanned repair costs. The unplanned repairs have to be done to remove the defects which appear on a building wall overcladding during its service life. In order to do that the authors have performed the expert's surveys of technical condition of the existing overcladdings. These overcladdings were assembled on the external walls of 497 apartment buildings located in Wrocław (Poland) in 1990 $\div 2000$. The qualitative results of technical condition expert's surveys, their transformation into the quantitative values done according to the elaborated model and estimation of the risk related to the expected profit decrease are presented in the article.
\end{abstract}

Keywords: risk, economic efficiency, overcladding system.

\section{Introduction}

There are lots of economic formulae, eg [1, 2], which are used in the decisions-making process of investments. The above formulae are adjusted to the scale of an investment (macro- or micro-economics), take into account diversification of money in time (static or dynamic), distinguish the conditions of an investment activity (deterministic or probabilistic). The correct selection of an economic formula requires to distinguish the main aims of an investment. It is also necessary to estimate the terms of the investment (which include the costs and the profits) as well as to estimate the investment risk. The analysis of economic formula selection, suitable for a decision-making process in building projects, is presented in [3].

The problem analysed in the article refers to a situation in which an investor has already taken a decision about the kind of a project. At this stage of procedure, the economic efficiency of a wall overcladding system is estimated according to the NPV (Net Present Value) formula and, if necessary, a comparison of possible use of overcladding systems is made according to the NPVR (Net Present Value Ratio) formula. However, the result of estimation includes a risk of an expected profit. The risk might be the result of some external factors (ie changes of an interest rate) or the internal properties of a project effecting the changes of the expected cash flow or the planned economic or technical durability. The above factors cause that the risk depends on the conditions specific for a country in which an investment takes place. In a special bibliography there are papers concerning the general problems of risk understanding and risk management, eg [4-6], and papers concerning the adaptation of the general rules to some particular country needs, eg [7, 8 ] as well as papers concerning some practical problems.

The authors have examined the dependence of the cash flow upon the building technical features of a project. The estimation of events probability, which can have an effect on a project profit during the succeeding years of its service life, is the main subject of the article.

A building project is an investment with long-term effects. Apart from the building costs, it also contains the operating costs (including the planned repair costs). The scope of the planned repairs is specified during the design stage according to the technical features of the building elements. However, there are also unplanned repairs during the building or its elements service life. They are caused by design and construction failures as well as unexpected defects caused by external conditions. Therefore, there must be borne in mind the additional costs, which can have a significant effect on the cash flow. Alas, the unplanned repair costs are usually not taken into account in the calculation of the economic efficiency of building projects.

Some building elements can have different suppleness in the unplanned repairs during their service life. It depends on the technical features of building elements. The share of the unplanned repairs costs in the total cash flow is different as well and its influence depends on the parameters of the economic formulae. However, there are some building projects which have a high suppleness of the above features. The authors' researches and the overcladding technical condition examination [9] prove that the wall overcladding systems can be classified by the building elements like these. The assembled wall overcladding systems have a very complicated structure and are sensitive to assembling conditions. At the same time, 
the cost of the overcladding work in Poland presents a considerable value in the economic formulae. The profit from the heat energy savings (after building external walls overcladding) is made not till several years payback period. Assuming 30 $\div 50$ years of the overcladding system durability, the cost of the unplanned repairs may have a considerable effect on the expected profit. Therefore, the scope of the unplanned repairs is an element of risk, which should be taken into account in the economic estimation. The result of this estimation is the main information in the decision-making concerning the external walls overcladding work. It should be noticed, however, that the above problem goes beyond the technical wear of building elements. The methods of technical wear estimation of buildings and their elements, eg [10, 11], concern the overall technical wear of an element in a moment of its service life. Whereas in the above problem, the repair costs of each defect of an overcladding element (during the whole service life) are the most important factors.

The methodical approach to the problem requires to arrange the qualitative description of defects, to elaborate the estimation method of their scope and frequency of their occurrence, and finally to elaborate the transformation method of qualitative results into the quantitative values, so they can be inserted into the economic formulae. The decision-making theory deals with the general rules of transformation of qualitative results into the quantitative values, eg [12]. However, each particular case requires elaborating a transformation model.

The authors have already examined the theoretical problem of risk in the building external walls overcladding projects [13] (by making some a priori estimations). Then they examined the practical problem of risk in the same projects [14] (by expert's surveys of the technical condition of existing wall overcladdings). Original methods were elaborated for both the theoretical and the practical procedures. They were elaborated according to the degree of information/data reliability. They were able to transform qualitative description of defects into quantitative values so that they could be inserted into the economic formulae. The properties of wall overcladding systems were analysed taking into account their internal factors which can cause the defects. The á priori estimation was done using the subjective probability. The results of research are presented in $[15,16]$. Next, some practical research was done. It concerned defects in existing building wall overcladdings. They were analysed as the effects of wall overcladdings properties as well as the effects of some design and construction failures [14]. For both procedures the authors elaborated original methods according to the degree of information/data reliability. The procedure relating to the practical expert surveys of overcladdings as well as the whole procedure leading to the results which define the above problem are presented in the further part of the article.

\section{Characterisation of overcladding system}

The authors have done the technical condition expert's surveys of the existing overcladdings (it was so called the "lightweight" system of thermal insulation of external building walls) which were assembled on the external walls of the multi-family apartment buildings. The main purpose of the expert's surveys was to estimate the overcladdings technical conditions. The authors examined and analysed the technical condition of overcladdings assembled on the external walls of 497 apartment buildings (it is about $75 \%$ of apartment buildings with external walls overcladdings located in the town of Wrocław, Poland). The apartment buildings were built after 1970 , the service life of overcladdings $-2 \div 8$ years (ie they exceeded the guarantee period). The lightweight overcladding system has been used in Poland since 1990.

The assembling of the lightweight overcladding system consists in covering external surfaces of walls with uninterrupted, seamless coating - "facade system". The coating consists of the heat insulation (foamed polystyrene or mineral wool boards) stuck into a wall by an adhesive (additionally by fasteners, if necessary), reinforced by the glass fibre mesh stuck by an adhesive and external thin plaster. The foamed polystyrene (or mineral wool) presents insulation but at the same time it works as a separator eliminating the concentration of local stress (eg caused by excessive thermal deformations of external wall which appear along the joints of wall panels and existing cracks) in the thin layer of the external plaster. This plaster protects external walls and the internal layers of overcladding system from weather conditions (ie rain, snow, sleet, UV radiation etc) and also improves the envelope appearance.

The wall overcladding work must be done precisely by the manufacturer's assembling instructions containing the requirements for the quality of overcladding system materials and the external conditions during assembling. For instance, it is recommended a 90-days seasoning of foamed polystyrene boards, only single pushing of foamed polystyrene boards when they are stuck to a wall, the external temperature from +5 to $+30{ }^{\circ} \mathrm{C}$. It is also not allowed to assemble during rain, sleet or snow as well as during wind blowing faster than $10 \mathrm{~m} / \mathrm{s}$. The above requirements are the results of the materials properties used in the overcladding systems, the way they are jointed together and the way the overcladding is stuck to an external wall.

The above characteristic qualifies the technical features of the overcladding system. It is not always possible to follow the manufacturer's assembling instructions on a building site. If the instructions are not fulfilled, the defects will appear on an overcladding system during its service life. The kind of a defect enables to indicate the technical feature of an overcladding which caused the defect.

The main purpose of the expert's surveys was to estimate the technical conditions of overcladdings as well as to recognise the defects causing the need of the unplanned repairs. The above defects were analysed using the effect-reason relation $[17,18]$ (ie with reference to the technical features of the examined lightweight overcladding system). The results of the analysis research are in Table 1. 


\section{Procedure method}

The results of the technical expertise are the defects which were recorded as qualitative data (Table 1). Therefore it was necessary to make a transformation of such recorded defects into quantitative values of finance risk (related to a building wall overcladding).

The authors elaborated the following original methodical procedure:

- $\quad$ problem formulation,

- a method which transforms defects qualitative description into quantitative values (with references to technical features of overcladding, causing the defects),

- $\quad$ estimation of probabilities of defects occurrence,

- $\quad$ estimation model (adaptation of the NPV formula to the problem requirements in order to estimate a finance risk of overcladding project).

\subsection{Problem formulation}

The defects, observed during the expert's surveys of overcladdings technical condition, cause the need of the unplanned repairs during the overcladding service life. The costs of the unplanned repairs will decrease the expected profit from the heat energy savings after external walls overcladding. The probability of the unplanned repairs need is determined by the frequency of the defects. Design and assembling failures are the direct reason of the overcladdings defects. Some technical features of particular overcladding systems might be recognised as an indirect reason of the overcladding defects. These are the technical features which unable to do the overcladding assembling in easy, fast and in quality way. Therefore, it is assumed that there is a risk concerning the expected profit from overcladding project caused by the internal features of the overcladding system. The measure of the risk is determined as a decrease of the expected profit form overcladding project related to the total profit and marked in percentage terms. It is necessary (for the risk estimation) to transform the results of overcladdings technical conditions expert's surveys into the numerical values. It enables to insert them into the NPV formula for estimating the economic efficiency.

\subsection{Transformation of qualitative description of over- cladding defects into quantitative values}

The notation of defects is done according to a very important assumption: the defect occurrence on the overcladding is a dichotomous variable noted in the binary system $\left\{U_{i}\right\}=[0,1]$ (if the defect occurs on the overcladding, it is noted as - " 1 "; if not, it is noted as " 0 "). The reasoning for the above notation is the following: in case of the overcladding system, it is more important the place on a wall, where a defect occurred, than the degree, scope, kind of a defect; it is because the place of defect occurrence has the general influence on the scope and kind of repair of overcladding (and at the same time on the costs). Therefore, we are more interested if a defect occurred or not (which implies - it is or it is not necessary to do a repair) than the defect degree, scope or kind.

\subsection{Estimation of probabilities of defects}

The results of the overcladdings technical conditions were elaborated by using the statistical inference. First of all it was determined a kind of defects distribution in the general population (assuming the defects are noted as variables from the set $\{0,1\})$. The non-parametric test of significance (ie chi-square test $\chi^{2}$ and KolmogorovSmirnov test) were used to determine the defects distribution. The test were done on the example of defect $U_{l}$. The results showed that the overcladding defects occurrence has a distribution approximated to the binomial distribution $B(n, p)$. The binomial distribution function is expressed by the relation:

Table 1. Analysis of defects of the lightweight overcladding system in the effect-reason relation

\begin{tabular}{|c|c|c|c|}
\hline \multirow{2}{*}{\multicolumn{2}{|c|}{$\frac{\text { Effect }}{\text { Overcladding defect }}$}} & \multicolumn{2}{|l|}{ Reason } \\
\hline & & \multirow{2}{*}{$\frac{\text { Caused by external factors }}{\text { Assembling failure }}$} & \multirow{2}{*}{$\begin{array}{c}\text { Caused by internal factors } \\
\begin{array}{c}\text { Technical feature of over- } \\
\text { cladding system }\end{array} \\
\end{array}$} \\
\hline Symbol & Description & & \\
\hline 1 & 2 & 3 & 4 \\
\hline$U_{1}$ & Offsets on overcladding surface & $\begin{array}{l}\text { Careless sanding of foamed polystyrene boards } \\
\text { surface and edges }\end{array}$ & \multirow{4}{*}{$\begin{array}{l}\text { Precise manufacturer's re- } \\
\text { quirements concerning as- } \\
\text { sembling of heat insulation }\end{array}$} \\
\hline$U_{2}$ & $\begin{array}{l}\text { Uneven (corrugated) overcladding } \\
\text { surface }\end{array}$ & \multirow{2}{*}{$\begin{array}{l}\text { Careless preparation of external wall surface } \\
\text { (cleaning, levelling) for sticking foamed polysty- } \\
\text { rene boards }\end{array}$} & \\
\hline$U_{3}$ & Overcladding drops off the wall & & \\
\hline$U_{4}$ & $\begin{array}{l}\text { Excessive dirt on overcladding } \\
\text { plaster }\end{array}$ & $\begin{array}{l}\text { Not smooth surface of foamed polystyrene boards } \\
\text { (the same reasons as in } U_{1}, U_{2}, U_{3} \text { ) }\end{array}$ & \\
\hline$U_{5}$ & Overcladding plaster drops off & Plaster work in external temperature below $+5^{\circ} \mathrm{C}$ & \multirow{3}{*}{$\begin{array}{l}\text { Suppleness of overcladding } \\
\text { system on weather condi- } \\
\text { tions }\end{array}$} \\
\hline$\overline{U_{6}}$ & $\begin{array}{l}\text { Scratches, cracks on overcladding } \\
\text { surface }\end{array}$ & $\begin{array}{l}\text { Plaster work on external wall exposed to the ex- } \\
\text { cessive Sun's rays }\end{array}$ & \\
\hline$U_{7}$ & $\begin{array}{l}\text { Washed out colour from plaster, } \\
\text { uneven surface quality of plaster }\end{array}$ & $\begin{array}{l}\text { Plaster work in high external humidity (drizzle, } \\
\text { rain) } \\
\text { Plaster work during high wind speed }>10 \mathrm{~m} / \mathrm{s}\end{array}$ & \\
\hline
\end{tabular}




$$
B(n, p, k)=P(X=k)=C_{n}^{k} p^{k} q^{n-k},
$$

where: $k=0,1,2, \ldots, n, n-$ sum of independent random variables, $p$ - probability of success (it is assumed that the success is a situation when a defect occurs on overcladding; it is noted as " 1 "), $q$ - probability of failure (it is assumed that the failure is a situation when a defect does not occur on overcladding; it is noted as "0").

Because it is assumed that the result of each experiment can be only one of two stages - success or failure, so $p+q=1$.

The method of parametric interval estimation is used for estimating of the probability of defects occurrence on the overcladdings.

The frequency of defect occurrence in the examined population $m / n$ is taken as the estimator of the unknown probability $p$ of a defect occurrence in the general population. The significance level is 0,95. The estimator selection is done according to Bernoulli and Glivenko's theorem.

The confidence interval (with the significance level equal to 0,95 ) for the probability of particular defect occurrence $U_{i}$ in the general population is estimated from the relation:

$$
\frac{m}{n}-t_{\alpha} \sqrt{\frac{\frac{m}{n}\left(1-\frac{m}{n}\right)}{n}}<P\left(U_{i}\right)<\frac{m}{n}+t_{\alpha} \sqrt{\frac{\frac{m}{n}\left(1-\frac{m}{n}\right)}{n}},
$$

where: $P\left(U_{i}\right)$ - unknown probability of defect occurrence $U_{i}, n$ - examined population size, $m$ - number of defects occurrence $U_{i}, t_{\alpha}$ - value form the table of variable $\tilde{T N}(0,1)$ as the solution of equation $\phi\left(\tau_{\alpha}\right)=\frac{1-\alpha}{2}$.

For the interval (according to the relation above) the error of estimation is:

$$
\Delta=t_{\alpha} \sqrt{\frac{\frac{m}{n}\left(1-\frac{m}{n}\right)}{n}} .
$$

\subsection{Estimation model}

The NPV (Net Present Value) formula is modified to enable the risk effect estimation (which is a result of the need to do the unplanned repairs) on the overcladdings economic efficiency. The above modification generally consists in inserting into the formula a parameter which represents the risk. Most of the formula parameters are assumed as the deterministic variables and their numerical values have been deeply analysed in [14]. The cost of overcladding (ie the total cost of overcladding work) $\boldsymbol{I}$ is assumed as a deterministic variable. It is a short term cost (paid by an investor in the first year of an investment), so its value is known for an investor with sufficient certainty. The costs of the planned repairs $\boldsymbol{k}_{r p z}^{r}$ are assumed as a deterministic variable as well. The scope and terms of the planned repairs were analysed in detail [14] with taken into account the results/data from the theory of planned repairs. The profit forms the heat energy savings $\boldsymbol{Z}_{\boldsymbol{c}}$ after building walls overcladding is assumed as a deterministic variable too, because it is possible to estimate its value (eg according to energy audits, building expert's surveys, economic forecasts). Whereas the costs of the unplanned repairs $\boldsymbol{k}_{r i}^{r}$ are assumed as a random variable. The problem of the effect risk in the cash flow is presented in the specialist literature (eg [19]). However, the above problem is usually solved by using the methods of the subjective probability estimation. The above methods take into account the random factors; however, they do not estimate the problem in a sufficient way.

The own original method which enables to insert a parameter (which represents a risk) into the $N P V$ formula is presented in the article. The product $\boldsymbol{P}\left(\boldsymbol{U}_{\boldsymbol{i}}\right) \cdot \boldsymbol{k}_{\boldsymbol{r} i}^{\boldsymbol{r}}$ is a quantitatively noted risk effect on the overcladdings economic efficiency. When it is inserted into the NPV formula, it becomes a parameter representing the costs of the unplanned repairs (which are the results of the defects occurrence probability).

The method of the parametric interval estimation enables to calculate not only one value of probability but the interval in which (with probability - 0,95) there is the unknown value of parameter $P$. For the calculation it has been assumed the maximum and minimum values (ie $P\left(U_{i}\right)_{\min }$ and $\left.P\left(U_{i}\right)_{\max }\right)$. The subjective probability is replaced with the probability estimated according to the results form of the own expert's surveys. The above replacement has minimised the effect of subjective factors on the calculated value of probability.

The chosen NPV (Net Present Value) formula is a base for a model elaboration. The model estimates the risk effect on the overcladdings economic efficiency. Because the total cost of overcladding work is paid in the first year $(t=0)$, so the $N P V$ formula is:

$$
N P V=\sum_{t=0}^{n} \frac{D_{t}}{(1+i)^{t}}-I,
$$

where: $I$ - present value of investment cost (paid in year $t=0)[€], D_{t}-$ net cash flow in the succeeding years of the calculation period $[€], i$ - interest rate [\%], $t$ - service life of an investment [years].

The further $N P V$ formula modification consists in replacing the particular parameters of the $N P V$ formula by the parameters concerning the overcladding system, ie

- $\boldsymbol{D}_{\boldsymbol{t}}-$ net cash flow in the succeeding years of the calculation period:

- $\quad \boldsymbol{Z}_{\boldsymbol{c}}$ - incomes (profits) form the heat energy savings due to a building external walls overcladding,

- $\quad$ expenses (losses): $\boldsymbol{k}_{r p z}^{r} \boldsymbol{I}$ - the cost of the planned repairs and $\boldsymbol{k}_{r i}^{r} \boldsymbol{I}$ - the cost of the unplanned repairs (in the elaborated model it is assumed that the net cash flow is constant in each year of an overcladding service life; the profits and the losses are calculated and noted as a function of the total cost of overcladding work).

- $\quad \boldsymbol{I}[€]-$ present value of investment cost - the total cost of overcladding work,

- $\quad \boldsymbol{i}$ - interest rate (it is assumed according to the recommendations for Polish economic conditions; for year $2000 i=6,5 \%$ ), 
- $t$ - service life of an investment; it is a duration of the overcladding system (for the lightweight overcladding system $t=40$ years; it is well founded to take such a long durability because the $N P V$ formula takes into account the costs of the planned repairs of overcladding, ie the features which guarantee to fulfil the durability).

and adding a parameter representing the risk effect, ie

- probability of particular defects occurrence in the general population $P\left(U_{i}\right)$. The product $P\left(U_{i}\right) \cdot k_{r i}^{r}$ is a parameter which quantitatively represents the risk effect in the $N P V$ formula.

Thus, the relation (4) is:

$$
E_{N P V}=\sum_{t=1}^{n} \frac{E_{t}}{(1+i)^{t}}-I,
$$

where: $E_{N P V}$ - expected value of the net present value $(N P V), E_{t}$ - expected value of the net cash flow in $t$ - year of an overcladding service life, $I, i, t-$ as above.

$$
E_{t}=\sum_{j=1}^{2} D_{t j} \times P_{t j}
$$

where: $P_{t j}$ - probability of $i$-level of the net cash flow in $t$ year, $P_{t j}\left(U_{i}\right)_{\min }, P_{t j}\left(U_{i}\right)_{\max }$,

$j=1,2-$ number of examined levels of the net cash flow; in the examined situation there are two levels of the net cash flow, there is or there is no a defect on the wall overcladding so there is or there is no need of the unplanned repairs of overcladding,

$P_{t 1}\left(U_{i}\right)_{\min } P_{t 1}\left(U_{i}\right)_{\max }$ - probability that there is no defect $U_{i}$ on the overcladding in the general population (it is a probability of failure $q$ - in the expert's surveys a failure is a situation when a defect does not occur on overcladding, it is noted as " 0 "),

$P_{t 2}\left(U_{i}\right)_{\text {min }} P_{t 2}\left(U_{i}\right)_{\text {max }}$ - probability that there is a defect $U_{i}$ on the overcladding in the general population (it is a probability of success $p$ - in the expert's surveys a success is a situation, when a defect occurs on the overcladding, it is noted as " 1 "),

$D_{t j}-i$-level of the net cash flow in $t$-year,

$D_{t 1}-i$-level of the net cash flow in $t$-year (without the unplanned repairs),

$D_{t 1}=Z_{c}-k_{r p z}^{r} \cdot I[€]$,

$D_{t 2}-i$-level of the net cash flow in $t$-year (with taken into account the unplanned repairs costs; ie with taken into account the risk),

$D_{t 2}=Z_{c}-k_{r p z}^{r} \cdot I-k_{r i}^{r} \cdot I$,

$Z_{c}$ - the mean profit in a year from the heat energy savings due to a building external walls overcladding $[€]$,

$k_{r p z}^{r}$ - index of mean cost of the planned repairs in one year [\%],

$k_{r i}^{r}-$ index of mean cost of the unplanned repairs in one year [\%].

Thus, the relation (5) is:

$$
E_{N P V}=\sum_{t=0}^{n} \frac{\left(D_{t 1} \times P_{t 1}+D_{t 2} \times P_{t 2}\right)}{(1+i)^{t}}-I
$$

For a complex estimation of the risk effect on the overcladding economic efficiency according to the NPV formula, it is necessary to calculate (apart from the expected value) the general statistical measures such as: variance $\sigma_{t}^{2}$, standard deviation $\sigma_{N P V}$, coefficient of variation $C V_{N P V}$. The level of $N P V$ standard deviation and coefficient of variation show the effect of risk related to the need of the unplanned repairs of the overcladding.

- Variance of the net cash flow for the succeeding years of an overcladding service life is calculated according to the relation:

$$
\sigma_{t}^{2}=\left(D_{t j}-E_{t}\right)^{2} \times P_{t j}
$$

where: $\sigma_{t}^{2}$ - variance of the net cash flow in the succeeding years of an overcladding service life, $D_{t j}, E_{t}, P_{t j}-$ as above.

- $\quad N P V$ standard deviation is calculated according to the following relation:

$$
\sigma_{N P V}=\sqrt{\sum_{t=1}^{n} \frac{\sigma_{t}^{2}}{(1+i)^{2 t}}}
$$

where: $\sigma_{N P V}-$ standard deviation $N P V, \sigma_{t}^{2}, t, i$-as above.

And it is calculated $N P V$ coefficient of variation according to the relation

$$
C V_{N P V}=\frac{\sigma_{N P V}}{E_{N P V}},
$$

where: $C V_{N P V}-N P V$ coefficient of variation, $\sigma_{N P V}-N P V$ standard deviation, $E_{N P V}-$ expected value of $N P V$.

\section{Results}

The risk effect on the overcladding economic efficiency is estimated by a model building. The model building represents the apartment, multi-family buildings which external walls overcladdings were surveyed by the authors. For the examined population of buildings, it is assumed an apartment, multi-family building, made of large-panel blocks, with 5 storeys, with 5 staircases, with a basement, the total area of walls with overcladding $1450 \mathrm{~m}^{2}$. The total cost of overcladding work (the lightweight overcladding system) $-20 € / 1 \mathrm{~m} 2$ of wall. The calculations are done on the model building because it was necessary to make $N P V$ comparison with the constant cost of the overcladding work $I$ and inconstant value of $D_{t j}$.

The results of calculation are shown in Table 2 . It is assumed (at the first stage of the calculation) that there is no defect on the overcladding, so there is no need to do the unplanned repairs (ie $k_{r i}^{r}=0$ as well as $P_{t 2}\left(U_{i}\right)_{\text {min }}=0$ and $P_{t 2}\left(U_{i}\right)_{\max }=0$ ). It is calculated $E_{N P V}$ (so called: the original $\left.E_{N P V}\right)$ (col 2) for the model building. Next, it is assumed (in the second stage of calculation) that there is a defect on the overcladding (which is a result of the design and the assembling failures), so there is a need to do the unplanned repairs (ie $k_{r i}^{r} \neq 0$ as well as $P_{t 2}\left(U_{i}\right)_{\text {min }} \neq 0$ and $\left.P_{t 2}\left(U_{i}\right)_{\max } \neq 0\right)$. However, it is assumed that there is only one defect on the overcladding (there are no other 
Table 2. Estimation of risk effect on overcladding system economic efficiency

\begin{tabular}{|c|c|c|c|c|c|c|c|c|}
\hline & \multirow{2}{*}{$E_{N P V}$} & \multirow[t]{2}{*}{$U_{i}$} & \multirow[t]{2}{*}{$k_{r i}^{r}\left(U_{i}\right)$} & \multirow{2}{*}{$\begin{array}{l}P_{t 2}\left(U_{i}\right)_{\min } \\
P_{t 2}\left(U_{i}\right)_{\max }\end{array}$} & \multirow{2}{*}{$\frac{E_{N P V(U i) \min }}{E_{N P V(U i) \max }}$} & \multirow{2}{*}{$\begin{array}{l}a_{\min }=E_{N P V}-E_{N P V(U i) \min } \\
a_{\min }=E_{N P V}-E_{N P V(U i) \max }\end{array}$} & \multirow{2}{*}{$\frac{\left(a_{\min } / E_{N P V}\right) \cdot 100 \%}{\left(a_{\max } / E_{N P V}\right) \cdot 100 \%}$} & \multirow{2}{*}{$\begin{array}{l}C V_{N P V \min } \\
C V_{N P V \max }\end{array}$} \\
\hline & & & & & & & & \\
\hline & {$[€]$} & \multirow{2}{*}{$\frac{[---]}{3}$} & [\%] & {$[\%]$} & {$[€]$} & {$[€]$} & {$[\%]$} & \multirow{2}{*}{$\begin{array}{c}\%] \\
9\end{array}$} \\
\hline $\begin{array}{l}\text { Overcladding } \\
\text { system }\end{array}$ & 2 & & 4 & 5 & 6 & 7 & 8 & \\
\hline \multirow{13}{*}{$\begin{array}{l}\text { Lightweight } \\
\text { overcladding } \\
\text { system }\end{array}$} & \multirow{12}{*}{7233} & \multirow[t]{2}{*}{$\overline{U_{1}}$} & \multirow[t]{2}{*}{1,70} & 16,0 & 5740 & 1493 & 20,6 & \multirow{2}{*}{$\begin{array}{l}11,4 \\
15,3\end{array}$} \\
\hline & & & & 24,0 & 4993 & 2240 & 31,0 & \\
\hline & & \multirow[t]{2}{*}{$U_{2}$} & \multirow[t]{2}{*}{1,70} & 8,00 & 6486 & 747 & 10,3 & \multirow{2}{*}{$\begin{array}{c}7,5 \\
10,9 \\
\end{array}$} \\
\hline & & & & 15,0 & 5833 & 1400 & 19,4 & \\
\hline & & \multirow{2}{*}{$U_{3}$} & \multirow[t]{2}{*}{0,25} & 0,00 & 7233 & 0 & 0,0 & \multirow{2}{*}{$\begin{array}{l}0,0 \\
0,4\end{array}$} \\
\hline & & & & 1,00 & 7219 & 14 & 0,2 & \\
\hline & & \multirow{2}{*}{$\begin{array}{l}U_{4} \\
U_{7}\end{array}$} & \multirow[t]{2}{*}{1,90} & 4,00 & 6816 & 417 & 5,8 & \multirow{2}{*}{$\begin{array}{l}5,7 \\
8,5 \\
\end{array}$} \\
\hline & & & & 8,00 & 6398 & 835 & 11,5 & \\
\hline & & $U_{5}$ & 0,38 & 11,00 & 7003 & 230 & 3,2 & 18,0 \\
\hline & & & & 18,00 & 6857 & 376 & 5,2 & 22,0 \\
\hline & & $U_{6}$ & 0,45 & 4,00 & 7134 & 99 & 1,4 & 13,0 \\
\hline & & & & 9,00 & 7011 & 222 & 3,1 & 19,0 \\
\hline & \multicolumn{8}{|c|}{$\begin{array}{l}\text { - explanation of signs in point } 3 \\
\text { - explanation of calculation in point } \\
\text { - "min" and "max" values are the val }\end{array}$} \\
\hline
\end{tabular}

defects) caused by the design and the assembling failures. It is also examined a situation when there are two defects on the overcladding. It is calculated, the expected value of the net present value $E_{N P V(U i)}$ for the building (col 6) for each situation. The result of a subtraction $a=N P V-$ $N P V\left(U_{i}\right)$ (col 7) (as a percentage of $N P V$ value) is a measure of the risk effect on overcladding system economic efficiency (col 8). The values of $N P V$ coefficient of variation $C V_{N P V}$ (which characterises the risk scope) are presented in column 9.

\section{Conclusions}

The results of calculation enable to formulate the following suggestions concerning the risk effect on the overcladding system economic efficiency:

- Overcladding system economic efficiency consists of the risk which is a result of the technical features of overcladding system. The following suggestion concern the lightweight overcladding system.

- The risk scale results from the kind of an overcladding defect and the probability of a defect occurrence. In respect of the kind of defect, it is very important the defects locations on the overcladding surface. These defects cause the higher costs of the unplanned repairs (Table 2, col $4-U_{1}, U_{2}, U_{4}, U_{7}$ ). The defects locations in the inside layers of the overcladding system and their technical results seem to be less important. Such defects do not cause technical consequences (Table 2, col. $4-U_{3}, U_{5}, U_{6}$ ). Defect $U_{1}$ (Table 1) is the most probable to occur on the lightweight overcladding system (Table 2, col 5). Defect $U_{1}$ causes the highest risk effect on the economic efficiency (Table 2, col 7). Defect $U_{5}$ (Table 1) is the second most probable defect to occur (Table 2, col 5). However, its local character minimises the influence on the risk scale. Defect $U_{2}$ (Table 1) has a significant effect on the examined risk (Table 2, col 7). It is a result of its character and its occurrence frequency.
- The statistical analyses of the results enable to make more discerning the estimation of risk causes. The defects causes are usually referred to the failures during assembling work. However, the analyses of statistics characteristics (Table 2, col 5, col 8) of defects $U_{1}$ and $U_{2}$ (Table 1, col 1, col 2, col 3) and examination of defect $U_{3}$ (Table 1, col 1, col 2, col 3) enable to educe the following conclusion: the assembling failures (which caused defects $U_{1}, U_{2}$ ) are generally caused by incorrect dimensions of the foamed polystyrene boards. The statistical characteristic (Table 2, col 5, col 8) of defect $U_{3}$ (Table 1, $\operatorname{col} 1, \operatorname{col} 2, \operatorname{col} 3)$ is an example of assembling work precision. The statistical characteristic (Table 2, col 5, col 8) of defects $U_{6}, U_{7}$ (Table 1, col 1, col 2, col 3) shows that the above defects are party caused by the suppleness of overcladding assembling work on the weather conditions. The probability of defects $U_{5}$ and $U_{6}$ occurrence can be minimised by a proper assembling work organisation, eg in case of bad weather conditions, when overcladding assembling work is done at the same time on several external walls, it should be done the assembling work that is not sensitive to the weather conditions (eg assembling of scaffoldings, preparing the external wall surface) or the assembling work should be done on the external wall that is not exposed to weather conditions (eg on the external wall which is not exposed to the Sun's rays).

- The lightweight overcladding system was designed according to the strict technological requirements. It is very sensitive to the external features (eg dimension tolerances of heat insulation materials, worker competencies, organisation possibilities of a contractor, the weather conditions).

- At the same time the lightweight overcladding system is one of the most frequent chosen overcladding systems. Because it gives a possibility to shape a building facade in many ways as well as it can be as- 
sembled by using simple in application, light and not expensive building equipment.

- Examination of the risk connected with the use of the lightweight overcladding system enables to estimate the profit form of the overcladding project. Indication of the risk reasons enables to minimise the risk (eg it is possible to make detailed control of assembling work in the moments when the most frequent failures are done which cause the defects occurrence in the overcladding during its service life).

\section{References}

1. Sierpińska, M. and Jachna, T. Estimation of Company According to World Standard. Warsaw: PWN, 1998. 277 p. (in Polish).

2. Kamerschon, D. R.; MacKenzie, R. B. and Nardinelli, C. Economy. Gdańsk: Economic Foundation of NSZZ "Solidarność", 1991. 979 p. (in Polish).

3. Marcinkowska, E. Decision Assistance in Building Projects According to Economic Criterion. In: Proc of XLII Scientific Conference KILiW PAN and KN PZITB "Scientific and Research Problems of Building Engineering", Krynica, 1997. Lectures Vol VII "Technology and Organisation”, 1997, p. 51-56 (in Polish).

4. Bendell, A.; Weightman, D. W. and Walker E. V. Applying proportional hazards modelling in reliability. Reliability Engineering and System Safety, 34(1), 1991, p. 35-53.

5. Mok, C. K.; Rao Tummala, V. M. and Leung H. M. Practices, Barriers and Benefits of Risk Management Process in Building Services Cost Estimation. Construction Management and Economics, 15(2), March 1997, p. 161-175.

6. Raftery, J. Risk Analysis in Project Management. E\&FN SPON, 1994. 123 p.

7. Bajaj, D.; Oluwoye, J. and Lenard, D. An Analysis of Contractors' Approaches to Risk Identification in New South Wales, Australia. Construction Management and Economics, 15(4), July 1997, p. 363-369.

8. Bizon-Górecka, J. Risk Management in Construction Production. Archives of Civil Engineering, 45(4), 1999, p. 543-551.
9. Marcinkowska, E. and Rejment, M. Technology Risk in Building Projects. In: Proc of XLI Scientific Conference KILiW PAN and PZITB "Scientific and Research Problems of Building Engineering", Krynica 1996. Lectures Vol 6, "Technology and Organisation of Building Engineering”, 1996, p. 165-172 (in Polish).

10. Marcinkowska, E. Technical and Functional Requirements of Building Deterioration Estimation. Archives of Civil Engineering, XLVIII(1), 2002, p. 125-134.

11. Konior, J. and Marcinkowska, E. Analysis of Technical Wear of Old Apartment Houses in Wrocław. In: Proc of International Conference on Developments in Building Technology, Slovakia, Sept 1996, p. 203-210.

12. Roy, B. Méthodologie Multicritère de Aide à la Décision. Paris: Editions Economica, 1990. 281 p. (in French).

13. Marcinkowska, E. Technological and Economic Efficiency of Apartment Buildings Thermorenovation. Report SPR Series No 2/96, Wrocław: Stage IV, Estimation of Solutions and Conclusions, Institute of Building Engineering, Wrocław University of Technology, Poland, 1996. 83 p. (in Polish).

14. Rejment, M. Buildability Effect on Building Projects Efficiency on Example of Building Thermomodernisation. Report Series PRE No 27/01, PhD thesis, Institute of Building Engineering, Wrocław University of Technology, Poland, 2001. 132 p. (in Polish).

15. Marcinkowska, E. and Rejment, M. Quantitative Description of Project Solution Producibility of Apartment Building Thermorenovations. Archives of Civil Engineering, 43(2), 1997, p. 189-198.

16. Marcinkowska, E. and Rejment, M. Selection Optimisation of Building Thermal Overcladding Technical Variants. In: Proc of $6^{\text {th }}$ International Conference "Modern Building Materials, Structures and Techniques", 19-21 May 1999, Vilnius, Lithuania. Vilnius: Technika, 1999, p. 121-128.

17. Their, H. Cases of Damage and Their Analysis. Deutscher Verlag fuer Schweisstechnik. Duesseldorf, 1985. 186 p.

18. Weil, G. J. Detecting the Defects. ASCE Civil Engineering, 59(9), 1989, p. 74-77.

19. Bowlin, O. D.; Martin, J. D and Scott, D. F. Guide to Financial Analysis. New York: McGraw-Hill, 1980. 335 p.

\section{RIZIKOS ITAKA EKONOMINIAM PASTATO APDARO SISTEMOS EFEKTYVUMUI}

\section{E. Marcinkowska, M. Rejment}

\section{S antrauka}

Priimant sprendimus apie pastato išorinių sienų apdaro ịrengima, atsižvelgiama ị pelną, kuris laukiamas igyvendinus apdaro projekta. Laukiamasis pelnas skaičiuojamas pasitelkiant ekonomines diskontavimo formules. Šios formulès neịvertina neplanuotų išlaidų pastato apdarui remontuoti. Neplanuoti remontai turi būti atliekami apdaro eksploatavimo periode atsirandantiems defektams šalinti. Autoriai nusprendè tirti šią problemą ir tam atliko egzituojančių pastatų apdaro būklès ekspertinị vertinimą. 1990-2000 m. buvo tirtos 497 gyvenamujų pastatų Vroclave (Lenkija) išorinès sienos. Kokybiniai vertinimo rezultatai buvo transformuoti i kiekybinius, pasitelkiant išsamų autorių sukurtą modelį. Remiantis pastaraisiais rezultatais, buvo įvertinta laukiamojo pelno sumažejimo rizika. Rizikos vertinimas aprašytas šiame straipsnyje.

Reikšminiai žodžiai: rizika, ekonominis efektyvumas, sienų apdaras.

Ewa MARCINKOWSKA. Professor of civil engineering in Wrocław University of Technology, Poland. She is a member of Section of Organisation and Management in Construction - PAN, Committee of Civil Engineering and Mechanics - PAN, Committee of Science PZiTB. Her research interests include: technology of construction work, decision problems in construction, project management and building maintenance. Also a Chief of Division of design and construction methods of buildings in Wroclaw University of Technology.

Mariusz REJMENT. Reader of civil engineering in Wrocław University of Technology, Poland. His research interests: organisation and technology of construction work, cost calculation, building maintenance. 